International Environmental Law and Policy Series

\title{
Oceans Law and Policy in the Post-UNCED Era: Australian and Canadian Perspectives
}

Edited by

Lorne K. Kriwoken, Marcus Haward,

David VanderZwaag and Bruce Davis

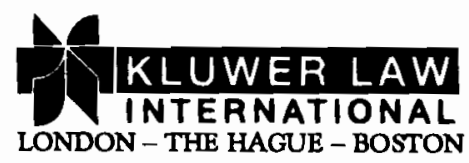




\section{Scipeoh}

$\therefore$

it $+1 !$

12324

1906

Published by

Kluwer Law International Ltd

Sterling House

66 Wilton Road

London SW1V 1DE

United Kingdom

KJuwer Law International Ltd incorporates the publishing programmes of

Graham \& Trotman Ltd,

Kluwer Law \& Taxation Publishers

and Martinus Nijhoff Publishers.
Sold and distributed in the USA and Canada by

KJuwer Law International

675 Massachusetts Avenue

Cambridge MA 02139

USA

In all other countries, sold and distributed by Kluwer Law International

P.O. Box 85889

$2508 \mathrm{CN}$ The Hague

The Netherlands
ISBN 90-411-0937-4

@ Kluwer Law International 1996

First published 1996

British Library Cataloguing in Publication Data

A catalogue record for this book is available from the British Library

Library of Congress Cataloguing-in-Publication Data is available

\section{THE \\ UNIVERSITY \\ OF TASIANANIA \\ LIBRARY}

This publication is protected by international copyright law. All rights reserved. No part of this publication may be reproduced, stored in a retrieval system, or transmitted in any form or by any means, electronic, mechanical, photocopying, recording or otherwise, without the prior permission of the publisher.

Printed and bound in Great Britain by Hartnolls Ltd, Bodmin, Cornwall

\section{The International Environmental Law and Policy Series}

Series General Editor

Stanley P. Johnson

Advisory Editor

Günther Handl

Other titles in the series

Transferring Hazardous Technologies and Substances, G. Handl, RE. Lutz (ISBN 0-86010-704-3)

Understanding US and European Environmental Law: A Practitioner's Guide,

T.T. Smith, P. Kromarek

(ISBN 1-85333-305-0)

Air Pollution Control in the European Community: Implementation of the EC Directives in the Twelve Member States, G. Bennett (ed.)

(ISBN 1-85333-567-3)

Intemational Responsibility for Environmental Harm, F. Francioni and T. Scovazzi (eds.)

(ISBN 1-85333-579-7)

Environmental Protection and Intemational Law, W. Lang, H. Neuhold, K. Zemanek (eds.) (ISBN 1-85333-611-4)

Intemational Law and Global Climate Change, R. Churchill, D. Freestone (eds.)

(ISBN 1-85333-629-7)

Intemational Legal Problems of the Environmental Protection of the Baltic Sea, M. Fitzmaurice

(ISBN 0-7923-1402-6)

Basic Documents of Intemational Environmental Law, H. Hohmann (ed.)

(ISBN 1-85333-628-9)

The Antartic Envimnmental and Intemational Law, J. Verhoeven, P. Sands, M. Bruce (eds.) (ISBN 1-85333-630-0)

Environmental Pollution Control: An Introduction to Principles and Practice of Administration,

J. McLoughlin, E.G. Bellinger

(ISBN 1-8533-577-0)

The Earth Summit: The United Nations Conference on Environment and Development (UNCED), S.P. Johnson

(ISBN 1-85333-784-6)

Amazonia and Siberia: Legal Aspects of the Preservation of the Envinnment and Development in the Last Open Spaces, M. Bothe, T. Kurzidem, C. Schmidt (eds.)

(ISBN 1-85333-903-2)

Pollution Insurance: Intemational Survey of Coverages and Exclusions, W. Pfennigstorf (ed.)

(ISBN 1-85333-941-5)

Civil Liability for Transfrontier Pollution, G. Betlem

(ISBN 1-85333-951-2)

Transboundary Movements and Disposal of Hazardous Wastes in Intemational Law,

B. Kwiatowska, A.H.A. Soons

(ISBN 0-7923-1667-3)

The Legal Regime for Transboundary Water Pollution: Between Discretion and Constraint,

A. Nollkaemper

(ISBN 0-7923-2476-5)

The Environment after Rio: Intemational Law and Economics, L. Campiglio, L. Pineschi,

D. Siniscalco, T. Treves (eds.)

(ISBN 1-85333-949-0) 
Overcoming National Bamiers to Intemational Waste Trade, E. Louka

(ISBN 1-7923-2850-7)

Precautionary Legal Duties and Principles in Modem Intemational Environmental Law,

H. Hohmann

(ISBN 1-85333-077-0)

Negotiating Intemational Regimes: Lesson Leamed from the UN Conference on Environmental and Development, B. Spector, G. Sjöstedt, I. Zartman (eds.)

(ISBN 1-85966-077-0)

Conserving Europe's Natural Heritage: Towards a European Ecological Network, G. Bennett (ed.)

(ISBN 1-85966-090-8)

US Environmental Liability Risks, J.T. O'Reilly

(ISBN 1-85966-093-2)

Environmental Liability and Privatization in Central and Eastem Europe, G. Goldenmann et al (eds.)

(ISBN 1-85966-094-0)

German Environmental Law, G. Winter (ed.)

(ISBN 0-7923-3055-2)

The Peaceful Management of Transboundary Resources, G.H. Blake et al (eds.)

(ISBN 1-85966-173-4)

Pollution from Offshore Installations, M. Gavouneli

(ISBN 1-85966-186-6)

Sustainable Development and Intemational Law, W. Lang

(ISBN 1-85966-179-3)

Canada and Marine Environmental Protection, D. Vanderzwaag

(ISBN 90-411-0856-4)

The Environmental Policy of the European Communities, S.P. Johnson, G. Corcelle (ISBN 90-411-0862-9)

Intemational Law and the Conservation of Biological Diversity, M. Bowman, C. Redgwell (eds.) (ISBN 90-411-0863-7)

Participation in World Treaties on the Protection of the Environment: A Collection of Data,

M.C. Maffei, L. Bineschi, T. Scovazzi, T. Treves (eds.)

(ISBN 90-411-0879-3)

Global Forests and Intemational Envinonmental Law, Canadian Council on International Law/

Conseil canadien de Droit international (ed.)

(ISBN 90-411-0897-1)

European Environmental Law, J. Salter (Looseleaf Service)

(Basic Work ISBN 1-85966-050-9)

(Please order by ISBN or title)

\section{Contents}

Preface

Contributors

Abbreviations and Acronyms

Introduction

The Evolving Oceans Agenda: From Maritime Rights to

Ecosystem Responsibilities

David VanderZwaag, Bruce Davis,

Marcus Haward and Lorne K. Kriwoken

1. UNCLOS III and UNCED: A Collision of Mind

Sets?

Douglas M. Johnston

2. National Responses to UNCED Outcomes: Australia Bruce Davis

3. Canadian Oceans Policy and UNCED Judith Swan

4. Australia and the Law of the Sea: Recent Developments and Post-UNCED Challenges Donald R. Rothwell

5. Canada and the Law of the Sea: Perspectives and Issues for Canadian Accession Aldo Chircop

6. Australian Ocean Boundaries: An Overview Stuart Kaye

7. Canada's Ocean Limits and Boundaries: An Overview Ted L. McDorman

8. Integrated Coastal Zone Management Marcus Haward and Lawrence P. Hildebrand

9. Marine Living Resources

Anthony Bergin, Marcus Haward,

Dawn Russell and Robert Weir

10. Developments in Australian and Canadian Marine Environmental Management

Lorne K. Kriwoken and Raymond P. Côté 
11. The Control of Vessel Source Pollution Edgar Gold

12. The Management of South Pacific Marine

Resources: Regional Institutions and Canadian

Development Assistance

Richard Herr and Phillip Saunders

13. Australia, the South Pacific and UNCED's

Oceans Agenda

Anthony Bergin and Frances B. Michaelis

14. Brokering Cooperation in the South China Sea

Ian Townsend-Gault

15. Environmental Protection in Antarctica and the

Southern Ocean: A Post-UNCED Perspective

Donald R. Rothwell

16. The Arctic Marine Environment: Not a Pristine

Pole Apart

David VanderZwaag, Ron Huebert and

Owen Hertzman

17. Comparative Perspectives on Indigenous

Rights to Marine Resources in Canada and Australia

Fay G. Cohen, Annette Luttermann and Anthony Bergin

Conclusion

Getting National Ocean Acts Together

David VanderZwaag, Bruce Davis,

Marcus Haward and Lorne K. Kriwoken

Index 
Douglas M. Johnston, Emeritus Professor of Law, Distinguished Senior Fellow, Centre for Asia-Pacific Initiatives, University of Victoria Victoria, Canada; Adjunct Professor of Law, Dalhousie Law School, Halifax, Canada.

Stuart Kaye, Lecturer, Law School, University of Tasmania, Hobart, Australia; Doctoral candidate Dalhousie Law School, Dalhousie University, Halifax, Canada.

Lorne K. Kriwoken, Lecturer, Centre for Environmental Studies; Research Associate, Oceans Policy and Overlapping Regimes Programme, Antarctic Cooperative Research Centre, University of Tasmania, Hobart, Australia.

Annette Luttermann, Graduate of the Master of Environmental Studies Program, School for Resource and Environmental Studies (SRES); and Research Assistant at SRES in 1995, Dalhousie University, Halifax, Canada.

Ted L. McDorman, Associate Professor, Faculty of Law and Associate, Centre for Asia-Pacific Initiatives, University of Victoria, Victoria, Canada; and Associate, Oceans Institute of Canada, Halifax, Canada.

Frances B. Michaelis, Senate Standing Committee, Environment, Recreation, Communications and the Arts, Parliament House, Canberra, Australia.

Donald R. Rothwell, Associate Dean (Postgraduate) and Senior Lecturer, Faculty of Law, The University of Sydney, Sydney, Australia.

Dawn Russell, Professor, Marine and Environmental Law Programme, Dean, Dalhousie Law School, Dalhousie University; and Associate, Oceans Instititute of Canada, Halifax, Canada.

Phillip Saunders, Assistant Professor, Marine and Environmental Law Programme, Dalhousie Law School and School for Resource and Environmental Studies, Dalhousie University; Associate, Oceans Institute of Canada, Halifax, Canada; and formerly South Pacific Field Representative for the International Centre for Ocean Development.

Judith Swan, SwanSea Oceans Environment Inc. and former Director of the Oceans Institute of Canada, Halifax, Canada.

Ian Townsend-Gault, Faculty of Law, University of British Columbia, Vancouver, Canada and Canadian Project Director of the Asia-Pacific Oceans Cooperation Programme.
David VanderZwaag, Professor, Marine and Environmental Law Programme, Dalhousie Law School and School for Resource and Environmental Studies, Dalhousie University; and Associate, Oceans Institute of Canada, Halifax, Canada

Robert Weir, Research Assistant, Marine and Environmental Law Programme, Dalhousie Law School, Dalhousie University, Halifax, Canada. 


\title{
Introduction
}

\section{The Evolving Oceans Agenda: From Maritime Rights to Ecosystem Responsibilities}

\author{
David VanderZwaag, Bruce Davis, \\ Marcus Haward and Lorne K. Kriwoken
}

The late twentieth century has witnessed an unprecedented increase in the number of international treaties and agreements relating to maritime issues and oceans governance. In part this reflects an attempt to reduce uncertainty in an era when the emergence of a new global strategic, political and economic order is creating tensions within and between nations; in part it reflects an attempt to resolve major issues of global environmental management with respect to marine jurisdictions; in part a recognition that the trade-off between conservation and development poses many complex questions requiring to be resolved through bi-lateral and multilateral discourse.

While each maritime regime has been created to meet an identified need or serve a particular purpose, more attention needs to be devoted to interrelationships since regime overlap can have beneficial, neutral or dysfunctional consequences. As we near the end of the current millennium, it is essential to determine how oceanic regimes should relate one to another.

The 1982 Law of the Sea Convention (LOSC), 1 while imposing general obligations on parties to protect the marine environment, is largely concerned with delineating national maritime rights. The Convention represents a 'zoning the oceans' codification balancing the marine resource and maritime enforcement rights of coastal states, port states and flag states. ${ }^{2}$

The 1992 United Nations Conference on Environment and Development (UNCED), urging states to promote the concept of sustainable development, has unleashed at least four major currents of change for ocean law and policy-making. Expanded responsibilities to protect marine and coastal ecosystems have emerged, or are in the process of emerging, from post-UNCED principles, programs, processes and priorities for action.

Perhaps the most powerful outcome of the UNCED was the new emphasis on principled decision-making. In the past international law had largely focused on interstate relations and taken almost a hands off approach to interfering with national sovereignty including state rights to exploit natural resources. Through the Rio Declaration on Environment and Development ${ }^{3}$ and Agenda 21,4 UNCED articulated numerous soft law principles that should guide not only international but also national ocean law and policy reforms. ${ }^{5}$ Those principles include integration, 
precaution, pollution prevention, intergenerational equity, polluter pays, public participation, community-based management, indigenous rights and women in development.

Another post-UNCED route for addressing the complexities of sustainable development has been through global conferences which have led to detailed programs of action for particular problem areas. Of particular relevance to marine environment protection is the recently concluded Global Programme of Action to Protect the Marine Environment from Land-based Activities. An intergovernmental conference, sponsored by the United Nations Environment Programme (UNEP) and held in Washington, D.C. from 23 October - 3 November 1995, adopted a Programme of Action having numerous promising aspects. States, among other things, have agreed to develop national programs of action establishing priorities and measures for managing pollution from point and non-point sources and strategies for protecting
coastal habitats.

A third horizon of hope are the various institutional processes established post-UNCED that may further develop law and policy approaches to support sustainable management of coastal and marine environments. The conventions on Climate Change 6 and Biologica Diversity 7 both established ongoing Conferences of the Parties which promise to further develop scientific understanding and management approaches. For example, at the first Conference of the Parties to the Framework Convention on Climate Change in Berlin (28 March - 7 April 1995), participants agreed to establish an open-ended, ad hoc group to negotiate by 1997 strengthened developed country commitments for addressing greenhouse gas emissions including appropriate action for the period beyond 2000.8 The Conference of the Parties to the Biodiversity Convention have adopted a program of work on marine and coastal biodiversity. ${ }^{9}$

A further key process in the post-UNCED era has been establishment and ongoing sessions of the UN Commission on Sustainable Development. Chapter 38 of Agenda 21 called for the formation of a Commission on Sustainable Development to monitor progress on Agenda 21 implementation by national governments organisations and to enhance dialogue with nongovernmental organisations. 10 UN General Assembly Resolution 47/191 in December, 1992 authorised the creation of the Commission on Sustainable Development (CSD). The CSD was finally established in February 1993 as a functional commission of the UN Economic and Social Council (ECOSOC). Composed of representatives from 53 nations, the Commission held its first substantive session in June 1993 and subsequent sessions in 1994 and 1995. The Commission is to consider the topics of oceans and the atmosphere at its 1996 session in New York. 11
Another process energised by UNCED was the convening of an intergovernmental conference on straddling fish stocks and highly migratory fish stocks. Spurred on by Canadian concerns over high seas over-fishing by foreign fleets beyond Canada's 200 nautical mile fishing zone off Newfoundland, Agenda 21 called for the convening of such a conference in Chapter 17, paragraph 17.50. UN General Assembly Resolution 47/192 established the Conference and negotiations for an international agreement took place through six sessions occurring between 1993 - 1995.12 A final Agreement for the Implementation of the Provisions of the United Nations Convention on the Law of the Sea of 10 December 1982 Relating to the Conservation and Management of Straddling Fish Stocks and Highly Migratory Fish Stocks ${ }^{13}$ was concluded in August 1995. The Agreement provides for high seas inspections by independent (non-flag state) inspectors, binding dispute settlement and adoption of the precautionary approach to fisheries management. 14

A contribution of Agenda 21 to national ocean law and policy development is the establishment of management priorities. Some of the important challenges coastal states are urged to address include:

- establishing/strengthening coordination mechanisms for integrated coastal zone management at both local and national levels (para. 17.6);15

- implementing integrated coastal and marine management plans and programmes (para. 17.6(b));

- protecting marine biodiversity including establishment of protected areas (para. 17.7);

- building and maintaining sewage treatment facilities (para 17.27(b));

- $\quad$ establishing/improving regulations and monitoring programmes to control effluent discharges and emissions (para. 17.28(a));

- $\quad$ promoting environmental impact assessments (para. 17.28(b));

- controlling inputs of nutrients (nitrogen and phosphorus) into coastal waters (para. 17.28(f));

- $\quad$ promoting the use of environmentally less harmful pesticides and fertilizers and alternative methods of pest control (para. 17.28(i));

- controlling non-point source pollutants (such as agricultural practices, mining, construction, transportation) (para. $17.28(\mathrm{j})$ );

- $\quad$ strengthening legal and regulatory frameworks for managing fisheries and aquaculture (para. 17.79(b)(c)(d)); and

- supporting sustainability of small-scale artisanal fisheries (para. 17.82).

This volume traces the implementation of two important global maritime regimes, the 1982 LOSC and outcomes of the 1992 UNCED in two federal, western middle-power nations, Australia and Canada. Comparative analysis of Australian and Canadian ocean law and policy in the post-UNCED era has been the focus of an ongoing research project 
by the Australia Canada Ocean Research Network (ACORN). ACORN involves Australian and Canadian academics and this network has been made possible by funding provided by the International Council of Canadian Studies and the Canadian government through the Canada Australia Bicentennial Research Award (CABIRA). The CABIRA is awarded to Australian academics to further comparative research with Canadian colleagues and originated as part of Canada's bicentennial gift to Australia in 1988

There have been two workshops held under the ACORN banner (1993 in Hobart, Australia and 1994 in Halifax, Canada). The major outcome of these meetings is this book. Twenty-one papers, presented by individuals expert in their fields have been combined into 17 chapters. The work of ACORN, and the research by individual members of the ACORN network, emphasises the utility of a comparative approach to research on oceans policy. Australia and Canada share some similarities yet also have significantly different pressures acting upon domestic responses to the post-UNCED agenda. These similarities and differences are nowhere more clearly illustrated than in responses to Agenda 21, Chapter 17.

The experiences of Australia and Canada in the post-UNCED era may provide some lessons for other states grappling with the need to develop integrated approaches to managing their ocean and coastal resources. Both countries have significant ocean domains and concomitan responsibilities following the entry into force of the LOSC in Novembe 1994, although Canada, unlike Australia, has yet to ratify LOSC. Table 1 provides a brief summary of the biogeographical, constitutional and sectoral elements of oceans policy in Australia and Canada. Each manages maritime zones on three oceans with the world's longest ice-free coastline (Australia, Figure 1) and the world's longest coastline (Canada, Figure 2) respectively. Both have significant interests in and involvement with oceans related capacity building in the Asia-Pacific region.

Internationally Australia and Canada have taken significant positions in international fora on oceans matters, although their positions have at times varied considerably. Canada took an active position in relation to coastal states' interests at the 1993-95 United Nations Conference on Straddling Fish Stocks and Highly Migratory Fish Stocks whereas Australia took equally important, yet arguably a more moderate, position. Australia remained committed to ensuring that the interests of South Pacific Island countries (dependent on effective management of highly migratory tuna, and tuna-like, species) were maintained. Australia's commitory tuna, legally binding instrument merged during the conference and reflected its involvement with Pacific Island states, and to a lesser extent with New
Zealand.

Table 1: Marine and Coastal Resources of Canada and Australia

\begin{tabular}{|c|c|c|}
\hline & Canada & Australia \\
\hline Population & $28,753,000$ & $17,627,000$ \\
\hline $\begin{array}{c}\text { Terrestrial area } \\
\text { (square kilometres) }\end{array}$ & $9,922,385$ & $\begin{array}{c}7,682,300 \\
\text { (plus Australian Antarctic } \\
\text { Territory 6,044,065) } \\
\end{array}$ \\
\hline Length of coastline (kilometres) & 243,789 & 36,735 \\
\hline Maritime area & $\begin{array}{c}5 \text { million square kilometres } \\
\text { (when Exclusive Economic } \\
\text { Zone declared) }\end{array}$ & $\begin{array}{l}8.94 \text { million square kilometres } \\
\text { (200 nautical mile Exclusive } \\
\text { Economic Zone, excluding } \\
\text { Australian Antarctic Territory) }\end{array}$ \\
\hline $\begin{array}{l}\text { Provinces, States and } \\
\text { Territories with maritime } \\
\text { jurisdiction }\end{array}$ & $\begin{array}{l}\text { British Columbia, Manitoba, } \\
\text { Ontario, Quebec, New } \\
\text { Brunswick, Nova Scotia, Prince } \\
\text { Edward Island, Newfoundland \& } \\
\text { Labrador, Northwest Territories, } \\
\text { Yukon Territory } \\
\end{array}$ & $\begin{array}{l}\text { Queensland, New South Wales, } \\
\text { Victoria, South Australia, } \\
\text { Tasmania, Western Australia, } \\
\text { Northern Territory, Australian } \\
\text { Capital Territory }\end{array}$ \\
\hline External Territories & none & $\begin{array}{c}7 \\
\text { Ashmore and Cartier Islands, } \\
\text { Australian Antarctic Territory, } \\
\text { Christmas Island, Cocos } \\
\text { (Keeling) Islands, Coral Sea } \\
\text { Islands, Heard Island and } \\
\text { McDonald Islands, Norfolk } \\
\text { Island } \\
\end{array}$ \\
\hline Oceans & Pacific, Atlantic, Arctic & Pacific, Indian, Southern \\
\hline $\begin{array}{l}\text { Biogeographical } \\
\text { representation }\end{array}$ & temperate, subpolar, polar & $\begin{array}{l}\text { tropical, subtropical, temperate, } \\
\text { subpolar, polar }\end{array}$ \\
\hline Latitudinal variation & 40 degrees & $\begin{array}{c}60 \text { degrees, Torres Strait to } \\
\text { Antarctica }\end{array}$ \\
\hline $\begin{array}{l}\text { Species of high } \\
\text { conservation value }\end{array}$ & $\begin{array}{l}\text { beluga whale, piping plover, } \\
\text { cod }\end{array}$ & $\begin{array}{c}\text { loggerhead and green turtle, } \\
\text { dugong, whale }\end{array}$ \\
\hline $\begin{array}{l}\text { Marine protected areas: } \\
\text { numbers, area (square km) }\end{array}$ & none formaily proclaimed & $\begin{array}{c}303 \\
463,200 \\
\end{array}$ \\
\hline $\begin{array}{l}\text { Species of high economic } \\
\text { value }\end{array}$ & $\begin{array}{l}\text { lobster, salmon, shrimp, crab, } \\
\text { scallop }\end{array}$ & rock lobster, prawn, abalone \\
\hline $\begin{array}{l}\text { Fisheries - value of total } \\
\text { exports }\end{array}$ & $\mathrm{C} \$ 2.66$ billion & A $\$ 1.37$ billion \\
\hline
\end{tabular}


Figure 1: Australian Offshore Responsibilities 16



Figure 2: Canadian Offshore Responsibilities

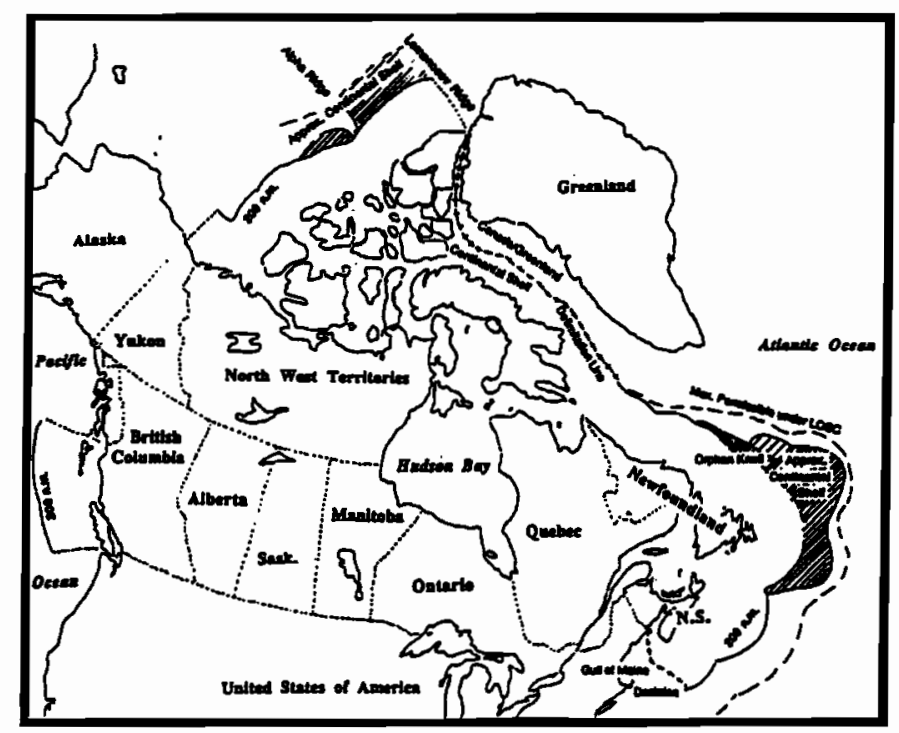

In relation to domestic law and policy both countries are also In relation to domending to Agenda 21 's oceans programs. As Australia and Canada are federations, the question of integration involves more than moving away from a sectoral focus for policy development and implementation. awas for role of sub-national governments (states/provinces/territories) may affect the implementation of Chapter 17. Important differences exist in the division of powers and responsibilities between the federal systems of Australia and Canada. In Australia the states retain significant responsibilities for ocean management, particularly within state waters (from the low water mark to 3 nautical miles offshore), while in Canada the federal government has primary role for ocean management notwithstanding the coastal provinces' interests in coastal management.

Explaining why variations in national and international approaches to ocean law and policy occur is not a simple assignment. For example it often assumed Canada and Australia ought to be similar, given often assumed Canadarliamentary systems, but the reality is that public policy issues are shaped by many factors. A variety of social, political, administrative and economic elements intrude.

This volume, while not covering all the dimensions of the postUNCED oceans agenda, does provide a spectrum of viewpoints on key facets of ocean law and policy developments and constraints in Australia facets of ocean Caw an 1 by Douglas Johnston discusses the tension in and Canada. Chapter United Nations Conference on the Law of the Sea mindsets between the United with the former emphasising sovereign (UNCLOS III) and UNCED, with the former emphasising sovereign entitlements and the latter state responsibility. Chapters 2 (BCED in the and 3 (Judith Swan) hector. Chapters 4 (Donald Rothwell) and 5 (Aldo Chircop) oceans sector. Chapters 4 (Donald Rothwell) in interpreting and summarise Australian and Canadian practice in interpreting and
implementing LOSC provisions. Chapters 6 (Stuart Kaye) and 7 (Ted implementing LOSC boundary issues and touch on remaining jurisdictional disputes.

boundary issues and touch on rexplore the ongoing searches for more The next four chapters explore the ongoing searches for more principled decision-making approaches in Australia and Canada Chapter 8 by Marcus Haward and Larry Hildebrand looks at national and subnational attempts to define and implement integrated coastal zone subnational attempts to define and implement Marcus Haward, Dawn Russell and Robert Weir, compares national approaches to marine living Russell and Robert Weir, compares nating management philosophies response management including brader coastal state rights over high towards precaution and supporting broader coastal state rights over high seas fishing. Chapter 10 by Lorne Kriwoken and Ray Côté describes including adoption of pollution prevention and marine protected area strategies. Edgar Gold's contribution, Chapter 11 on the control of vessel 
source pollution, focuses on inquiries over unsafe ships and discusses challenges in implementing the polluter pays principle.

Chapters 12-16 highlight national attempts to facilitate regional and inter-regional integration in ocean management. Richard Herr and Phillip Saunders (Chapter 12) consider the role of regional institutions and official development assistance in managing South Pacific marine resources. The theme is further examined by Anthony Bergin and Frances Michaelis in Chapter 13. Ian Townsend-Gault in Chapter 14, grapples with the problem of brokering cooperation in the South China Sea region. Chapter 15 by Donald Rothwell describes Australian concerns and efforts to protect Antarctica and the Southern Ocean, while Chapter 16 by David VanderZwaag, Rob Huebert and Owen Hertzman provides an update on initiatives to address the long-range movement of pollutants into the Arctic region.

Chapter 17, authored by Fay Cohen, Annette Luttermann and Anthony Bergin, concludes by surveying Canadian and Australian struggles to recognise and enhance the roles of indigenous people in marine resource management.

Clearly the United Nations Conference on Environment and Development and the 1982 Law of the Sea Convention do not represent end points. They promise to spark ongoing social, economic, political, ethical and legal changes. Principles, programs, processes and priorities have been set in motion. This book provides a glimpse of the initial ripple effect being experienced in two countries trying to live up to international environmental and maritime obligations. Whether the goal of sustainable seas and shores is reached remains to be seen.

\section{Notes and References}

110 December 1982, (1982) ILM 211261

2 See Johnston, D.M. 'Vulnerable coastal and marine areas: a framework for the planning of environmental security zones in the ocean', (1993) Ocean Development and International Law, 24, pp. 63-79.

313 June 1992 UN Doc A/CONF. 151/5/Rev. 1, (1992) ILM 31874.

313 June 1992, 4 Reprinted in S.P. Johnson (ed.), The Earh Sumat \& Trotman, Martinus Nijhoff, on Environment and Develo

5 For a discussion of the creative force of soft law principles, see Dupuy, P.M., 'Soft law and the international law of the environment', (1991) Michigan Journal of International Law, 12, pp. 420-435.

69 May 1992, (1992) ILM 31849.

69 May 1992, (1992) ILM 31849.

8 For a summary of commitments from the first Conference of the Parties, see (10 April 1995) Earth Negotiations Bulletin, 12, 21.

9 For a summary of the Second Session of the Conference of the Parties, see (19

November 1995) Earth Negotiations Bulletin, 9, 39.

10 Paraphs 38.11 to 38.14 , S.P. Johnson, note 4, pp. 492-493.

11 aragr 11 See B. Cicin-Sain, Reflections on UNCED implemente and coasts', paper presented at the 29th Annual Conference Of the Lans: Challenges of Institute, Sustainable Development and Preservation of the Oceans:

UNCLOS and Agenda 21, Denpasar, Bali, Indones

12 The final session concluded on 4 August 1995 .

133 August 1995, UN Doc. A/CONF. 164/33.

14 Parameters for application of the precautionary approach are set out in Article 6 and Ann Annex II of the Agreement. Parties are bid

implementing the precautionary approach. 15 The World Coast Conference held in the Netherlands in November 1993 further developed guidelines for integrated coastal zone management. Institutional approaches to coordination suggested were: a national planning agency, an interagency or interministerial council, a special coordinating commission or committee, or designation of a 'lead agency'. See The World Bank, Environment Department, Noordwijk Guidelines For Integrated Coastal Zone Management,

The Netherlands, 1-5 November, 1993, p. 9. 16 Sketch map showing the new Australian Exclusive Economic Zone and the approximate limits of a continental shelf as defined under Article 76 of LOSC. The sketch map was provided by P. Symonds of the Australian Geological Survey
Organisation (AGSO). Similar versions have been published by AGSO in AUSGEO News 25 (December 1994) and in Marinet News. 